\author{
Monika Cepil ${ }^{*}$ \\ Tomasz Figlus $^{* *}$ \\ Uniwersytet Łódzki \\ Wydział Nauk Geograficznych \\ Katedra Geografii Politycznej, Historycznej i Studiów Regionalnych
}

\title{
Wiejskie szkoły ewangelickie w okolicach Łodzi w XIX wieku - ujęcie geograficzno-historyczne
}

\section{Wprowadzenie}

Szkoły stanowią jeden z najbardziej interesujących elementów zagospodarowania przestrzennego wsi, a dawne budynki obiektów oświatowych są cenną pamiątką po niemieckich osadnikach zamieszkujących w XIX w. okolice Łodzi.

W publikacjach naukowych kwestia szkół ewangelickich przez długi czas pozostała na uboczu zainteresowań badaczy podejmujących problematykę dziejów osadnictwa i geografii historycznej regionu łódzkiego. Istotny wkład w rozwój badań na ten temat w szerszej skali przestrzennej stanowi niewątpliwie praca K.P. Woźniaka dotycząca niemieckiego osadnictwa wiejskiego między Prosną a Pilicą i Wisłą ${ }^{1}$. Informacje na ten temat, obejmujące również badany obszar, odnaleźć można w historiografii niemieckojęzycznej, np. w pracach historyczno-osadniczych A. Breyera, O. Heikego, E. Kneifela². Zagadnienie to podlegało analizie w opracowaniach odnoszących się do szkolnictwa w całych Prusach Południowych, autorstwa D. Łukaszewicza, lub na marginesie zasadniczych rozważań dotyczących oświaty w Księstwie Warszawskim i Królestwie Polskim pióra

M. Cepil, doktorantka, Uniwersytet Łódzki, Wydział Nauk Geograficznych, Katedra Geografii Politycznej, Historycznej i Studiów Regionalnych, e-mail: monika_cepil@wp.pl

** T. Figlus, dr, adiunkt, Uniwersytet Łódzki, Wydział Nauk Geograficznych, Katedra Geografii Politycznej, Historycznej i Studiów Regionalnych, e-mail: tomasz.figlus@geo.uni.lodz.pl

1 K.P. Woźniak, Niemieckie osadnictwo wiejskie między Prosnq a Pilicq i Wisłq od lat 70. XVIII wieku do 1866 roku - procesy i jego interpretacja, Łódź 2013, s. 207-232.

2 O. Heike, 150 Jahre Schwabensiedlungen in Polen 1795-1945, Leverkusen 1979; A. Breyer, Deutsche Gaue in Mittelpolen, Leipzig 1935; tenże, Zur Gesichte des deutschen Schulwesens in Mittelpolen, „Deutsche Monatshefte in Polen”, Jg 6, 1939-1940, H. 8/9, s. 307-316; E. Kneifel, Gesichte der Evangelisch-Augsburgischen Kirche in Polen, Niedermarschacht 1962. 
E. Podgórskiej i A. Winiarza ${ }^{3}$. Niekiedy podstawą odniesienia mogą być również studia poświęcone szkolnictwu ewangelickiemu z tego okresu w innych regionach, np. opracowanie W. Cabana dla powiatu radomskiego, A. Breyera dla ziemi gostynińskiej czy H. Textora dla rejonu Przedecza ${ }^{4}$. Ekscerpcja materiałów źródłowych na temat wsi podłódzkich stanowiła dla autorów asumpt do pogłębienia tej problematyki w odniesieniu do badanego obszaru, szczególnie w nieporuszonym do tej pory aspekcie lokalizacyjno-fizjonomicznym.

Celem artykułu jest zbadanie szkół ewangelickich w wybranych wsiach zasiedlonych w XIX w. w okolicach Łodzi przez społeczność niemiecką, określenie ich genezy, lokalizacji i zasięgu oddziaływania oraz zasad funkcjonowania. Na potrzeby artykułu przeprowadzono kwerendy w Archiwum Państwowym w Łodzi i Archiwum Państwowym w Poznaniu. Przestudiowano materiały źródłowe odnoszące się różnych aspektów funkcjonowania szkół i źródła kartograficzne niezbędne z punktu widzenia dokładnej lokalizacji badanych obiektów. Przy ocenie współczesnego stanu zachowania elementów dziedzictwa kulturowego dokonano inwentaryzacji terenowej.

Na wstępnie warto dodać, że ze względu na ograniczony zasób materiałów źródłowych w artykule analizie zostaną poddane tylko wybrane obiekty oświatowe obrazujące specyfikę procesów społeczno-osadniczych w XIX w. Wszystkie badane obiekty zlokalizowane są we współczesnych granicach województwa łódzkiego.

\section{Geneza i wybrane aspekty funkcjonowania szkół}

W początkowym stadium formowania osady zasiedlonej przez ewangelików kwestia zakładania szkół nie była uregulowana prawnie. W społecznościach lokalnych nacisk kładziono jednakże na właściwe wychowanie dzieci i młodzieży, które było zapewnione przez szkolnictwo wyznaniowe. Ze względu na słabo rozwiniętą sieć parafii ewangelickich pojawiła się instytucja kantoratu. Budynek kantoratu pełnił również często funkcje świątynne. Z czasem nazwa ta trwałe powiązana została z wiejskimi szkołami ewangelickimi ${ }^{5}$. W ogromnej większości

3 D. Łukaszewicz, Szkolnictwo w Prusach Południowych (1793-1806) w okresie reform oświeceniowych, Poznań-Warszawa 2004; E. Podgórska, Szkolnictwo elementarne w Księstwie Warszawskim i Królestwie Polskim 1807-1831, Warszawa 1960; A. Winiarz, Szkolnictwo Księstwa Warszawskiego i Królestwa Polskiego (1807-1831), Lublin 2002.

4 W. Caban, Szkolnictwo ewangelickie w dawnym powiecie radomskim w pierwszej połowie $X I X$ w., [w:] „Biuletyn Kwartalny Radomskiego Towarzystwa Naukowego” nr 1/2, 1984, s. 12-18; A. Breyer, Die Entwicklung des deutschen Schulwesens in Gostyniner Lande (1780-1936), „Deutsche Monatshefte in Polen”, Jg 4, 1937/1938, H. 2/3, s. 105-114; H. Textor, Das deutsche Schulwesen in der Gemeinde Przedecz in der Zeit 1800-1830, „Deutsche Blätter in Polen”, Jg 6, 1929, H. 2, s. 133-141.

5 I. Bożyk, Osadnictwo niemieckie na terenach wiejskich między Pilicq a Wisła w latach 1815-1864, Kielce-Łódź 2015, s. 222-223; D. Łukasiewicz, dz. cyt., s. 16 i 62. 
koloniści byli wyznawcami luteranizmu ${ }^{6}$ oraz ewangelikami reformowanymi. Inną grupę wyznaniową stanowili herrnhuci zamieszkujący Nowosolną. Wśród kolonistów niemal nie spotykało się katolików ${ }^{7}$.

Zanim w kolonii wystawiono budynek szkoły, zdarzało się, że jeden z osadników oddawał na jej potrzeby izbę w chałupie lub zajęcia odbywały się kolejno w domach wszystkich gospodarzy. Uruchomienie i budowa kantoratu trwały czasem kilka lat od wytyczenia kolonii ${ }^{8}$. Jednym z pierwszych obiektów oświatowych we wsiach podłódzkich była, założona w 1793 r., szkoła w Pustkowej Górze $^{9}$. W 1800 r. swoje działanie rozpoczęła szkoła w osadzie Olechów ${ }^{10}$. W kolonii Łaznowska Wola obiekt edukacyjny utworzono w 1802 r. $^{11}$, rok później powstała natomiast szkoła w Nowosolnej ${ }^{12}$. W Bukowcu szkołę wybudowano w 1806 r. $^{13}$, a w Starowej Górze dopiero w 1809 r. ${ }^{14}$ Budynek szkoły w Rudej - Bugaj istniał już na pewno w $1817 \mathrm{r} .{ }^{15}$ Borowa własnego obiektu oświatowego doczekała się dopiero w 1820 r., a Zielona Góra w 1841 r. ${ }^{16}$

W pierwszych latach funkcjonowania szkół nauczycielami często były osoby nie posiadające odpowiednich kwalifikacji. W Starowej Górze pierwszym nauczycielem został syn jednego z kolonistów - Johann Heinrich Lohrer. Natomiast w Łaznowskiej Woli posadę nauczyciela powierzono lekarzowi Johannowi Rondthalerowi, pochodzącemu z Prus. Zdarzało się, że nauczyciel przybywał do

6 J. Cieślar, Etapy osadnictwa niemieckiego i pierwsze próby organizacji życia religijnego, [w:] A. Machejek (red.), Die Lodzer Deutschen - Niemcy łódzcy, Łódź 2005, s. 54.

7 A. Breyer, dz. cyt., s. 68; O. Heike, dz. cyt., s. 65.

8 O. Kossmann, Die Anfänge des Deutschtums im Litzmannstäter Raum Hauländer und Schwabensiedlung, Leipzig 1942.

9 Archiwum Państwowe w Łodzi [dalej: APŁ], Senior Łódzkiej Diecezji Ewangelicko-Augsburskiej [dalej: SŁDEA], Akta dotyczące religijnej ewangelickiej szkoły i cmentarza w Pustkowej Górze, sygn. 47.

10 APŁ, SŁDEA, Akta towarzystwa szkolnego szkół elementarnych w Bukowcu i Starowej Górze, sygn. 226.

11 APŁ, Szkoła Powiatowa w Rawie [dalej: SPR], Akta tyczące się szkoły elementarnej kolonii Łaznowska Wola w obwodzie rawskim położonej, sygn. 142.

12 H. A. Schöller, Neu-Sulzfeld/Nowosolna 23.Mai 1801-17. Januar 1945, Illustrierte historisch-geographische Erinnerungen an ein Dor fund seine Menschen, Selbsverlag, Erlangen 2009.

13 APŁ, Dyrektor Gimnazjum w Piotrkowie [dalej: DGP], Elementarna Szkoła w kolonii Bukowiec, sygn. 20.

14 APŁ, DGP, Starowa Góra, Powiat Piotrkowski, Szkoła Elementarna Ewangelicka Męska, sygn. 81.

15 Archiwum Państwowe w Poznaniu [dalej: APP], Albert Breyer - spuścizna, Kopia prawa Olędrów Brażyckich (Odpis ekstraktu ksiąg grodzkich łęczyckich oblaty kontraktu zawartego 1782 t. I między Walentym Chobrzyńskim i olędrami otrzymującymi zarośla na pustkowiach Wierzbny, Bugaju, Rudy i innych należących do dóbr Brużyca pow. łódzki), sygn. 647.

16 E. Kneifel, H. Richter, Die evangelisch-lutherische Gemeinde Brzeziny bei Lodz/Polen 1829-1945, Vierkirchen/Schwaben 1983, s. 19-20, K.P. Woźniak, Pruskie osiedla liniowe w okolicach Łodzi i ich mieszkańcy w poczqtkach XIX wieku, [w:] „Acta Universitatis Lodziensis, Folia Geographica Socio-Oeconomica”, t. 21, Łódź 2015, s. 111. 
osady wraz z grupą kolonistów ${ }^{17}$. Często korzystano z mieszkańców innych miejscowości. W Pustkowej Górze stanowisko nauczyciela pełnił syn nauczyciela z Tkaczewskiej Góry ${ }^{18}$, natomiast w Bukowcu przez wiele lat prowadzącym zajęcia był syn nauczyciela z kolonii Kochanów ${ }^{19}$. Można odnotować przypadki, w których szkoły przez dłuższy czas nie mogły znaleźć odpowiedniej osoby do nauczania. Sytuacja taka dotyczyła Liliopola, gdzie nauczyciela nie było przez trzy lata z powodu słabego uposażenia ${ }^{20}$.

Program nauczania obejmował umiejętności czytania i pisania w języku niemieckim oraz rachunki ${ }^{21}$. Jednym z podstawowych przedmiotów była religia ${ }^{22}$. W niektórych szkołach obywały się także zajęcia z robótek ręcznych czy śpiewu (dwa razy w tygodniu). Przedmioty były wykładane według wyznaczonego planu zajęć i przyjętego odgórnie klucza nauczania. W kolejnych latach funkcjonowania szkół lekcje odbywały się codziennie, zgodnie z planem godzinowym, a uczniowie podlegali ocenie okresowej, obejmującej egzaminy ${ }^{23}$. Każdy dzień nauki rozpoczynał się i kończył modlitwą. W pierwszych latach funkcjonowania obiektów edukacyjnych brak było podręczników, np. nauka czytania prowadzona była ze starych modlitewników i kalendarzy, przywiezionych jeszcze z Niemiec, z czasem do szkół stopniowo zaczęto wprowadzać podręczniki ${ }^{24}$. Dzieci uczęszczały do szkoły jedynie w okresie zimowym: od św. Marcina (11 listopada) do świąt Wielkonocnych ${ }^{25}$, gdyż w innych porach potrzebne były do pomocy w gospodarstwie $^{26}$. Szkoły składały się z kilku oddziałów. Dla przykładu szkoła w Bukowcu w 1837 r. składała się z trzech klas. Do grupy początkującej uczęszczało 16 dzieci. Drugą grupę stanowiły osoby czytające i piszące (11). Do trzeciej, ostatniej klasy, uczęszczało wówczas 23 dzieci ${ }^{27}$.

Z czasem władze dążyły do uzyskania kontroli nad szkolnictwem religijnym, stopniowo przejmując szkoły kantorowe i ustanawiając szkoły elementarne $^{28}$. W pierwszej połowie XIX w. władze administracyjne podejmowały próby

17 E. Kneifel, H. Richter, dz. cyt., s. 28, K.P. Woźniak, Niemieckie osadnictwo..., s. 94, M. Klemba, Czerwone piętno, Skierniewice 2014, s. 9-11.

18 APŁ, SŁDEA, Akta dotyczące religijnej ewangelickiej szkoły i cmentarza w Pustkowej Górze, sygn. 47.

19 APŁ, DGP, Elementarna Szkoła w kolonii Bukowiec, sygn. 20. Słownik Geograficzny Królestwa Polskiego i innych krajów słowiańskich, red. F. Sulimierski, W. Walewski, Warszawa 1880, t. V, s. 231.

21 APŁ, SŁDEA, Akta dotyczące religijnej ewangelickiej szkoły i cmentarza w Pustkowej Górze, sygn. 47. Z. Szeląg, Osadnictwo niemieckie w grójeckim. Słownik. Historia, kultura, gospodarka, Grójec 2011, s. 79.

23 APŁ, SŁDEA, Akta dotyczące religijnej ewangelickiej szkoły i cmentarza w Janowie, sygn. 42.

24 APŁ, DGP, Elementarna Szkoła w kolonii Bukowiec, sygn. 20. T. Stegner, Rola Kościoła ewangelickiego w życiu kolonistów niemieckich w Królestwie Polskim, [w:] Niemieccy osadnicy w Królestwie Polskim 1815-1915, red. W. Caban, Kielce 1999, s. 188. 
wprowadzenia jednolitego systemu szkolnictwa, niezależnego od pochodzenia i wyznania. W 1840 r. wprowadzono przepisy regulujące funkcjonowanie szkół elementarnych ${ }^{29}$. W 1873 r. w obiekcie oświatowym w Pustkowej Górze uczyło się 34 dzieci, z czego 32 było wyznania ewangelickiego, a dwie osoby pochodziły $\mathrm{z}$ rodziny rzymskokatolickiej ${ }^{30}$. W Słowiku $\mathrm{w}$ tym samym roku naukę pobierało 58 uczniów wyznania ewangelickiego oraz 28 osób wyznania rzymskokatolickiego $^{31}$. W wielu koloniach niemieckich pomysł ten jednak nie zyskał aprobaty, a osadnicy zakładali własne kantoraty $\mathrm{z}$ wykładowym językiem niemieckim ${ }^{32}$, gdzie zatrudniano na etat nauczyciela ewangelika ${ }^{33}$. W niektórych koloniach sami mieszkańcy podejmowali uchwały o przekształceniu kantoratu w szkoły elementarne $\mathrm{w}$ celu uzyskania dotacji rządowych ${ }^{34}$. Taki przypadek miał miejsce w 1864 r. w Borowej. Z czasem zaczęto dostrzegać wady organizowania własnych szkół w koloniach niemieckich, gdyż podtrzymywały one odrębność osadników w stosunku do otoczenia polskiego ${ }^{35}$.

Według rozporządzenia $1849 \mathrm{r}$. szkoły ewangelickie i ich nauczyciele przeszły pod nadzór Konsystorza ${ }^{36}$. Nauczyciela, pełniącego także funkcje kantora, wybierał pastor wraz z dozorem cmentarnym, np. pod opieką parafii w Nowosolnej znajdowały się szkoły w Janowie ${ }^{37}$ i Justynowie ${ }^{38}$. Przy wyborze starano się, aby kantor posiadał także kwalifikacje do pełnienia funkcji nauczyciela ${ }^{39}$.

Czynnikiem decydującym o sprawnym funkcjonowaniu szkół było zapewnienie jej finasowania. Stosunkowo dobrze radzili sobie koloniści w większych osadach, w których składka wystarczała na utrzymanie budynku, opłacenie nauczyciela oraz niezbędne wyposażenie szkoły. Ustalono odgórnie pensję dla nauczyciela w pieniądzu i naturaliach, np. w ziarnach, warzywach oraz udział w zysku z gruntu szkoły. Wypłata dla nauczyciela nie mogła być niższa niż 45 rubli $^{40}$, poza tym każdy nauczyciel zobowiązany został do płacenia składek rentowych ${ }^{41}$. Dla przykładu dochody szkoły w Wiączyniu Górnym za lata 1842-1847 wynosiły rocznie 52 rb. 72 kop., z czego nauczyciel pobierał 45 rb. rocznie ${ }^{42}$. W Starowej Górze w 1845 r. na pensję dla nauczyciela przeznaczono 28 rb. 75 kop., rocznie

\footnotetext{
29 Dziennik Praw Królestwa Polskiego [dalej: DPKP], 1844, t. 35, s. 275.

30 APŁ, SŁDEA, Akta dotyczące religijnej ewangelickiej szkoły i cmentarza w Pustkowej Górze, sygn. 47.

31 APŁ, SŁDEA, Akta dotyczące elementarnej ewangelickiej szkoły w Słowiku, sygn. 48.

32 I. Bożyk, dz. cyt., s. 223.

33 E. Kneifel, H. Richter, dz. cyt. s. 44.

34 T. Stegner, dz. cyt., s. 190.

35 K.P. Woźniak, Niemieckie osadnictwo wiejskie..., s. 212.

36 DPKP, 1849, t. 42, s. 223-225.

37 APŁ, SŁDEA, Akta dotyczące religijnej ewangelickiej szkoły i cmentarza w Janowie, sygn. 42.

38 APŁ, SŁDEA, Akta dotyczące religijnej ewangelickiej szkoły w Justynowie, sygn. 43.

39 DPKP, 1849, t. 42, s. 99-101.

40 DPKP, 1844, t. 35, s. 278.

41 DPKP, 1844, t. 35, s. 283.

42 APŁ, SŁDEA, Akta dotyczące elementarnej ewangelickiej szkoły i cmentarza w Wiączyniu Górnym, sygn. 49.
} 
na nagrody dla uczniów i materiały do nauki po 90 kop. ${ }^{43}$. Szkoły ponosiły wydatki na utrzymanie czystości, materiały piśmienne, nagrody dla uczniów i kupno książek i opału ${ }^{44}$. W Bukowcu do wydatków szkolnych doliczono również wizyty kominiarza ${ }^{45}$. W Justynowie za zaopatrzenie drewna na opał do szkoły odpowiedzialni byli mieszkańcy osady ${ }^{46}$. W skład przychodów szkoły wchodziły m.in. pieniądze ze sprzedaży: żyta, jęczmienia, grochu i tataraku oraz dochody z gruntów szkolnych i składki szkolnej od mieszkańców wsi, których dzieci uczęszczały do placówki ${ }^{47}$. Zdarzały się także sytuacje, że dana szkoła nie posiadała odpowiednich przychodów wystarczających na utrzymanie placówki i pensję dla nauczyciela. W związku z tym obiekty takie często zawieszały czasowo swoją działalność ${ }^{4}$. Przyczyny takiego stanu rzeczy bywały różne. Dla przykładu jednym z powodów zmniejszenia funduszy szkolnych był czasami zanik uczestnictwa w zajęciach dzieci wyznania rzymskokatolickiego, np. w Janowie ${ }^{49}$.

Wiejskie szkoły ewangelickie cieszyły się dobrą renomą, przykładem może być wzorowe funkcjonowanie szkoły w Kochanowie. Inspektor, wizytujący szkolę w kwietniu 1853 r., wysoko ocenił jej działalność. Odnotował, że jest ona bardzo dobrze wyposażona, w salach brakowało tylko zegara. Jeżeli chodzi o poziom nauczania, to inspektor chwalił nauczyciela za postępy w nauce uczniów ${ }^{50}$.

\section{Lokalizacja, zasięg oddziaływania i fizjonomia szkół}

Pierwsze wzmianki na temat prawa zakładania szkół ewangelickich pojawiały się w kontraktach osadniczych ${ }^{51}$. W osadach olęderskich, w których dokumenty lokacyjne były podpisywane z całą gminą, widniała informacja o ilości przedzielonych gruntów na tereny szkolne, ale najczęściej bez podania ich dokładnej lokalizacji ${ }^{52}$. Nieco inny charakter prawny posiadały kolonie niemieckie,

\footnotetext{
43 APŁ, DGP, Starowa Góra, Powiat Piotrkowski, Szkoła Elementarna Ewangelicka Męska, sygn. 81.

44 DPKP, 1844, t. 35, s. 279.

45 APŁ, DGP, Elementarna Szkoła w kolonii Bukowiec, sygn. 20.

46 APŁ, SŁDEA, Akta dotyczące religijnej ewangelickiej szkoły w Justynowie, sygn. 43.

47 APŁ, DGP, Elementarna Szkoła w kolonii Bukowiec, sygn. 20.

48 DPKP, 1844, t. 35, s. 279-281.

49 APŁ, SŁDEA, Akta dotyczące religijnej ewangelickiej szkoły i cmentarza w Janowie, sygn. 42.

$50 \quad$ M. Klemba, dz. cyt., s. 11.

51 O. Kossmann, Deutsche in Polen. Siedlungsurkunden 16.-19. Jh, Viersen 1995, s. 420-423.

52 APP, Albert Breyer - spuścizna, Kopia prawa Olędrów Brażyckich (Odpis ekstraktu ksiąg grodzkich łęczyckich oblaty kontraktu zawartego 1782 t. I między Walentym Chobrzyńskim i holędrami otrzymującymi zarośla na pustkowiach Wierzbny, Bugaju, Rudy i innych należących do dóbr Brużyca pow. łódzki), sygn. 647, APP, Albert Breyer - spuścizna, Gründungsurkunde der Kolonie Pustkowa Góra Kr Łęczyca (Odpis maszynowy z ksiąg grodzkich łęczyckich - 1785. 2.V), sygn. 752.
} 
zakładane w okresie Prus Południowych, w których podpisywano kontrakt indywidualnie z każdym osadnikiem. W materiałach źródłowych odnaleźć można jednak wzmianki o życiu religijnym mieszkańców i edukacji młodzieży ${ }^{53}$.

Gdy zaczęto ustanawiać kantoraty, istotne było podporządkowanie danej wsi do okręgu szkolnego, poprzedzone analizą terenową. Sprawdzano, czy dzieci idące do szkoły nie napotkają po drodze na utrudnienia komunikacyjne ${ }^{54}$. Nie każda osada niemiecka posiadała własną szkołę ewangelicką. Często kantorat lokalizowano w większych osadach i swoim zasięgiem obejmował mniejsze miejscowości. Z przeanalizowanych materiałów źródłowych można wnioskować, że do miejscowości, w których wystawiono szkołę uczęszczały również dzieci ewangelików zamieszkujących sąsiednie wsie o polskim rodowodzie. Warto przytoczyć kilka przykładów ukazujących obraz wiejskiej sieci szkół ewangelickich w okolicach Łodzi. Na zajęcia do Słowika, oprócz młodzieży miejscowej, chodziły także dzieci wyznania ewangelickiego z: Emilii, Adolfowa, Aleksandrii i Kaniej Góry ${ }^{55}$. W Bukowcu uczyły się dzieci z niemieckich rodzin mieszkających w Kraszewie ${ }^{56}$. Do szkoły wyznaniowej w Janowie uczęszczała młodzież z osady Ner oraz z Henrykowa ${ }^{57}$. Dzieci z miejscowości: Krasnodęby Nowe, Sobień, Chrosno oraz Prawęcin uczęszczały na zajęcia do szkoły w Krasnodębach Starych $^{58}$. Do szkoły w Pustkowej Górze na zajęcia chodziła młodzież z sąsiedniej kolonii Małogórne ${ }^{59}$. W dawnej olęderskiej kolonii Ruda-Bugaj uczyły się dzieci ewangelików z Brużyczki i Wierzbna ${ }^{60}$. Na prośbę mieszkańców wyznania ewangelickiego z Krzeszowa w 1842 r. mieszkańcy zostali odłączeni od szkoły rzymskokatolickiej w Kowalewicach i przydzieleni do szkoły ewangelickiej w Słowiku ${ }^{61}$. W latach 1878-1880 w szkole w Rudej-Bugaj uczyły się także dzieci z osad Wierzbno i Rafałów ${ }^{62}$.

W świetle analizy materiałów źródłowych, w tym kartograficznych, dostrzec można, że we wszystkich osadach szkoły umiejscawiano w obrębie niwy siedliskowej. W procesie rozwoju morfologicznego w większych niemieckich osadach, w których znajdował się zbór ewangelicki, szkoła znajdowała się w jego

\footnotetext{
53 O. Kossmann, Die Anfänge des Deutschtums..., O. Kossmann, Deutsche in Polen..., s. $420-423$.

54 K.P. Woźniak, Niemieckie osadnictwo wiejskie..., s. 210.

55 APŁ, SŁDEA, Akta dotyczące elementarnej ewangelickiej szkoły w Słowiku, sygn. 48.

56 APŁ, DGP, Elementarna Szkoła w kolonii Bukowiec, sygn. 20.

57 APŁ, SŁDEA, Akta dotyczące religijnej ewangelickiej szkoły i cmentarza w Janowie, sygn. 42.

58 APŁ, Szkoła Powiatowa w Łęczycy, Opis stanu szkoły elementarnej w kol. Krasnodęby, sygn. 67.

59 APŁ, SŁDEA, Akta dotyczące religijnej ewangelickiej szkoły i cmentarza w Pustkowej Górze, sygn. 47.

60 APŁ, SŁDEA, Akta tyczące wsi Ruda-Bugaj, sygn. 15.

61 APŁ, SŁDEA, Akta dotyczące elementarnej ewangelickiej szkoły w Słowiku, sygn. 48.

62 APP, Albert Breyer - spuścizna, Gerechtigkeit von Ruda-Bugaj (kopia, pow. sieradzki, woj. łódzkie) Aus dem polnischen die Gerechtigkeit ins deutsche übersetzt 1782. 6.I - Abschrift und Übersetzung im Jahre 1791 (oraz notatki dotyczące wsi Ruda-Bugaj), sygn. 758.
} 
sąsiedztwie. Dobrym przykładem takiego rozwiązania lokalizacyjnego jest Łaznowska Wola. Obiekt oświatowy mieścił się obok nieistniejącego już budynku zboru ewangelicko-augsburskiego. Budynek obecnie zlokalizowany jest w centralnej części wsi, przy drodze Łódź - Tomaszów Mazowiecki ${ }^{63}$.

W Bukowcu (ryc. 1) szkoła znajdowała się na pomiędzy osiedlem Bukowiec Dolny i Bukowiec Górny, przy dawnym kościele. Obiekt obecnie pełni funkcję mieszkaniową. Na działce, oprócz szkoły, zachował się także budynek gospodarczy i fragment murów kościoła z cegły. Zabudowa dawnej szkoły w Bukowcu posiada nietypowy kształt wieloboku ${ }^{64}$. Podobna sytuacja zaistniała w Borowej, gdzie wiejska szkoła ewangelicka powstała obok cmentarza i nieistniejącego już zboru w centralnym punkcie wsi ${ }^{65}$.

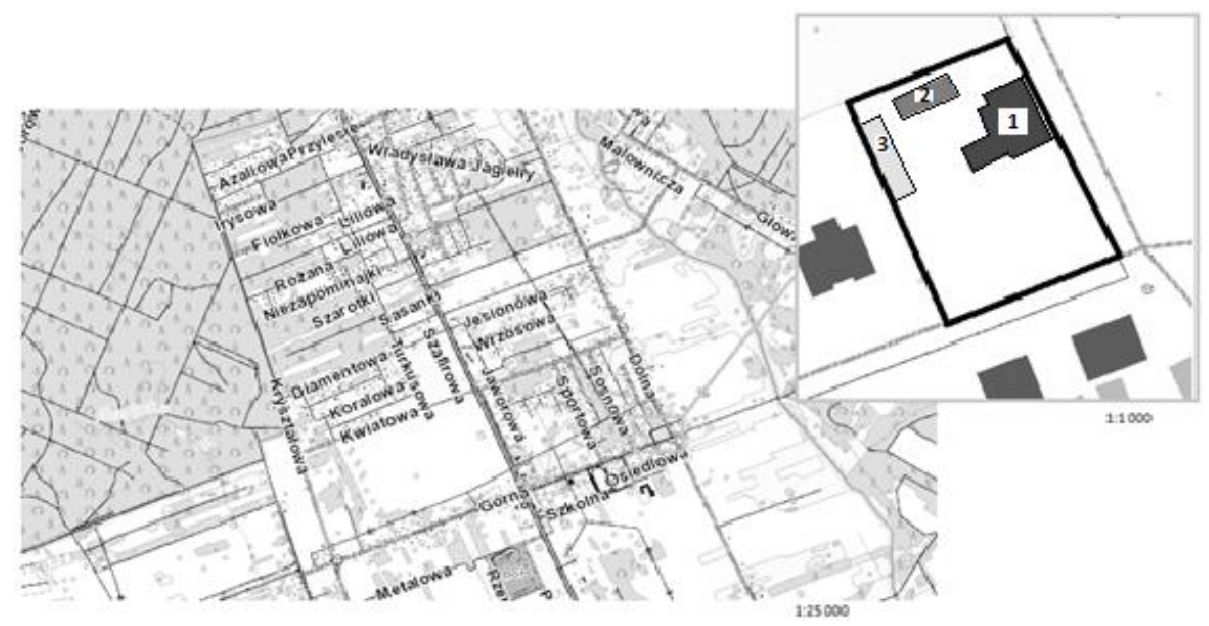

Ryc. 1. Obecne położenie dawnej szkoły w Bukowcu oraz układ przestrzenny jej działki: szkoła (1), pozostałości budynku gospodarczego (2), fragment ściany kościoła (3) Źródło: Opracowanie własne na podstawie www.geoportal.pl

W Nowosolnej, która posiada promienisto-koncentryczny układ ruralistyczny, szkołę ulokowano w centralnej części osady, w obrębie niwy siedliskowej pomiędzy dawną ul. Stokowską a ul. Łódzką. Od centralnego placu do szkoły prowadziła specjalnie wytyczona droga ${ }^{66}$.

63 M. Cepil, Kościół Ewangelicko-Augsburski w Łaznowskiej Woli, http://ziemiapiotrkowska.com/kosciol-laznowska-wola/ [dostęp: 28 II 2018]; J. Swiętorzecka, Z. Jasińska, 1985, Ewidencja Zabytkowej Zieleni, woj. piotrkowskie, gm. Rokiciny, obiekt: Łaznowska Wola, Stowarzyszenie Naukowo-Techniczne Inżynierów i Techników Rolnictwa. Okręgowy Ośrodek Rzeczoznawstwa i Doradztwa Rolniczego SITR, Wojewódzki Konserwator Zabytków w Piotrkowie Trybunalskim. 
Kolejnym, charakterystycznym miejscem lokalizacji szkoły, zwykle w dawnych osadach olęderskich, było sąsiedztwo cmentarza ewangelickiego. Obiekty oświatowe znajdowały się często na skraju zabudowy wsi, przy głównym ciągu komunikacyjnym. Można przypuszczać, że dobór właściwej lokalizacji szkoły stanowił odzwierciedlenie lokalnych uwarunkowań przyrodniczych i antropogenicznych ${ }^{67}$. W Słowiku szkoła znajdowała się w pobliżu cmentarza, przy obecnej drodze krajowej $\mathrm{nr}$ 91, w rejonie dzisiejszych torów tramwajowych ${ }^{68}$. Za niwą siedliskową, na południowym skraju osady, ulokowano kantorat i pierwszy dom modlitwy z Pustkowej Górze. Obecnie obiekt popada w ruinę ${ }^{69}$. Podobną lokalizacją cechował się obiekt w Rudzie-Bugaj ${ }^{70}$. Stwierdzić można, że w olęderskiej osadzie Janów budynek szkolny zlokalizowany był pierwotnie w miejscu sąsiadującym z powstałymi później torami kolejowymi, na wysokości ul. Augustów, zaraz za obecną stacją Łódź Widzew ${ }^{71}$.

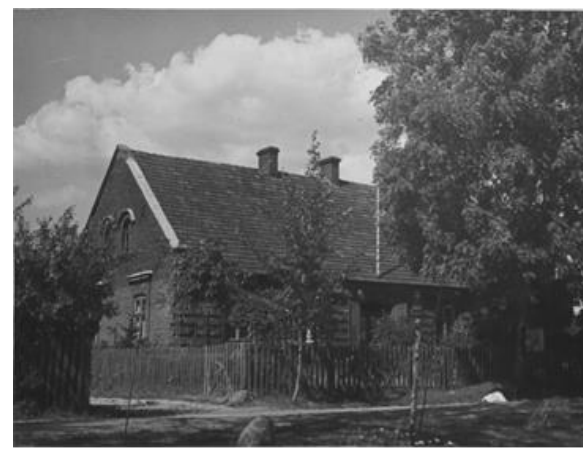

Ryc. 2. Murowany budynek szkoły w Markówce w okresie międzywojennym Źródło: Wojewódzka Biblioteka Publiczna w Łodzi, Regionalia3, sygn. FAO 5/76 PR

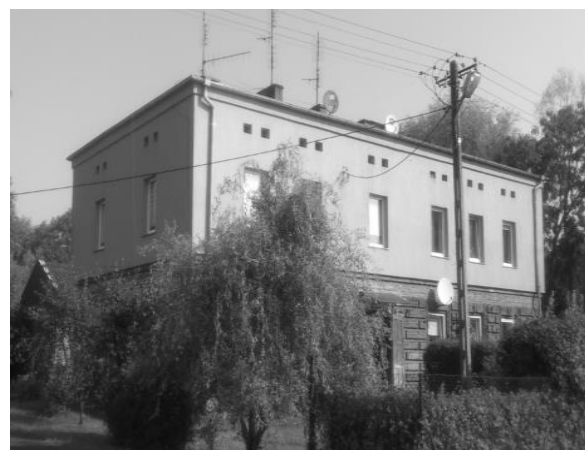

Ryc. 3. Obecny stan budynku dawnej szkoły w Markówce (wrzesień 2016) Źródło: M. Cepil

Inną grupę obejmują obiekty położone w koloniach niemieckich założonych w okresie istnienia Prus Południowych. Pierwotnie szkoły znajdowały się w obrębie niwy siedliskowej, zawsze przy głównej osi komunikacyjnej wsi. Jednym

67 T. Figlus, Wsie olęderskie w Polsce Środkowej, uwagi na temat zróżnicowania morfogenetycznego na tle rozwoju osadnictwa, ,Rocznik Łódzki”, t. LXII, 2014, s. 150.

68 M. Cepil, Osadnictwo olęderskie w Słowiku, „Zgierskie Zeszyty Regionalne”, t. 11, 2016, s. 308.

69 APŁ, SŁDEA, Akta dotyczące religijnej ewangelickiej szkoły i cmentarza w Pustkowej Górze, sygn. 47.

70 APP, Albert Breyer - spuścizna, Kopia prawa Olędrów Brażyckich (Odpis ekstraktu ksiąg grodzkich łęczyckich oblaty kontraktu zawartego 1782 t. I między Walentym Chobrzyńskim i olędrami otrzymującymi zarośla na pustkowiach Wierzbny, Bugaju, Rudy i innych należących do dóbr Brużyca pow. łódzki), sygn. 647.

71 APŁ, SŁDEA, Akta dotyczące religijnej ewangelickiej szkoły i cmentarza w Janowie, sygn. 42. 
z zachowanych budynków szkolnych jest obiekt usytuowany w Markówce (ryc. 2), pełniący aktualnie funkcję mieszkaniową. Współcześnie dobudowana została druga kondygnacja (ryc. 3). Szkoła znajduje się na zachodnim skraju wsi. Przy głównej drodze wiejskiej zidentyfikowano dawny budynek szkoły w Tkaczewskiej Górze ${ }^{72}$. Podobną lokalizacją ma zachowany do dziś budynek w Mikołajewie. Ze względu na brak wiarygodnych danych trudno jest niestety ustalić dokładną lokalizację niektórych szkół (np. Starowa Góra, Wygorzele, Olechów), choć z całą pewnością wiadomo o ich istnieniu.

W kontraktach osadniczych, zwłaszcza kolonii olęderskich, dokładnie została zaznaczona wielkość nadziału gruntowego przeznaczona na potrzeby szkoły. Według przeprowadzonych w 1842 r. pomiarów w Pustkowej Górze na działkę z budynkiem oświatowym przypadało 15 mórg $^{73}$. Taką samą powierzchnię przeznaczono na budowę szkoły w Słowiku ${ }^{74}$. W Janowie, po budowie linii kolejowej łączącej Łódź z koleją warszawsko-wiedeńską, grunty należące do szkoły zostały zmniejszone z 15 do 13 mórg $^{75}$. Na 14 morgach powstała szkoła w Rudej-Bugaj. Podobne powierzchnie gruntów na cele edukacyjne wyasygnowała większość miejscowości zamieszkałych przez ludność wyznania ewangelickiego $^{76}$.

Analizując akta poszczególnych szkół elementarnych, dowiadujemy się, że budynek zazwyczaj składał się z dwóch pomieszczeń. Jedno było przeznaczone do nauki, a drugie na mieszkanie dla nauczyciela ${ }^{77}$. W Wygorzelu (ryc. 4) budynek szkoły składał się z: mieszkania dla nauczyciela, kuchni, sali do nauki, kaplicy i korytarza ${ }^{78}$. Wielkość budynku bywała różna. Zwykle posiadała ok. 65 stóp długości, 32 stopy szerokości oraz 8,5 stóp wysokości ${ }^{79}$. Warto dodać, że pierwsze szkoły budowane były $\mathrm{z}$ drewna ${ }^{80}$. Wyróżnikiem szkoły był krzyż

72 Gmina Ewidencja Zabytków Gminy Parzęczew, 2015, szkoła w Tkaczewskiej Górze, GEZ 92.

73 APP, Albert Breyer - spuścizna, Gründungsurkunde der Kolonie Pustkowa Góra Kr Łęczyca (Odpis maszynowy z ksiąg grodzkich łęczyckich - 1785. 2.V), sygn. 752, APŁ, SŁDEA, Akta dotyczące religijnej ewangelickiej szkoły i cmentarza w Pustkowej Górze, sygn. 47.

74 Archiwum Główne Akt Dawnych w Warszawie [dalej: AGAD], Księgi ziemskie łęczyckie, ks. 146a, f.182.

75 APŁ, SŁDEA, Akta dotyczące religijnej ewangelickiej szkoły i cmentarza w Janowie, sygn. 42.

76 APŁ, SŁDEA, Akta tyczące wsi Ruda-Bugaj, sygn. 15.

77 APŁ, SŁDEA, Akta dotyczące religijnej ewangelickiej szkoły i cmentarza w Pustkowej Górze, sygn. 47.

78 APP, Albert Breyer - spuścizna, Schulchronik der Wygorzeler Schule (Remeberg Kr. Koło, woj. poznańskie); (Odpis koniki szkolnej i notatki dotyczące Wygorzeli i okolicy), sygn. 798.

79 D. Łukasiewicz, dz. cyt., s. 106.

80 APŁ, SŁDEA, Akta dotyczące religijnej ewangelickiej szkoły i cmentarza w Janowie, sygn. 42. 
umieszczony na dachu budynku ${ }^{81}$. W Bukowcu pierwsza drewniana szkoła została wystawiona przez jej mieszkańców ${ }^{82}$. W Łaznowskiej Woli szkoła została wybudowana w konstrukcji tzw. muru pruskiego, z dachem krytym słomą, posiadała 28 łokci długości oraz 19 łokci szerokości ${ }^{83}$.

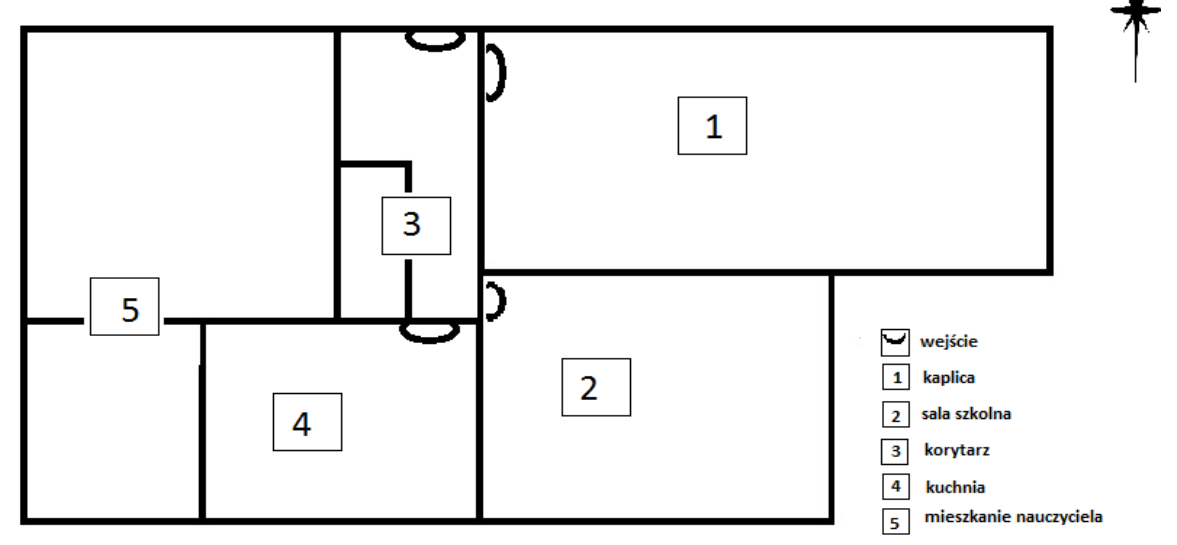

Ryc. 4. Odrys planu budynku szkolnego w Wygorzelu

Źródło: Opracowanie własne na podstawie: APP, Albert Breyer - spuścizna, Schulchronik der Wygorzeler Schule (Remeberg Kr. Koło), woj. poznańskie;

Odpis koniki szkolnej i notatki dotyczące Wygorzeli i okolicy, sygn. 798

W obrębie działki przeznaczonej pod teren szkoły znajdowała się także zabudowa gospodarcza, tj. stodoła i obora ${ }^{84}$ lub sama obora, jak w przypadku Pustkowej Góry ${ }^{85}$. W Łaznowskiej Woli w 1812 r. do obiektów szkolnych dobudowano oborę na węgiel, posiadającą długość 12 łokci oraz szerokość 5 łokci ${ }^{86}$. Zazwyczaj każdy nauczyciel otrzymywał indywidualny ogród lub odpowiednie wynagrodzenie w gotówce ${ }^{87}$. Zwykle ogród posiadał powierzchnię 4 mórg ${ }^{88}$.

81 K.P. Woźniak, Niemieckie osadnictwo wiejskie..., s. 191.

82 APŁ, DGP, Elementarna Szkoła w kolonii Bukowiec, sygn. 20.

83 APŁ, SPR, Akta tyczące się szkoły elementarnej kolonii Łaznowska Wola w obwodzie rawskim położonej, sygn. 142.

84 DPKP, 1844, t. 35, s. 277.

85 APŁ, SŁDEA, Akta dotyczące religijnej ewangelickiej szkoły i cmentarza w Pustkowej Górze, sygn. 47.

86 APŁ, SPR, Akta tyczące się szkoły elementarnej kolonii Łaznowska Wola w obwodzie rawskim położonej, sygn. 142.

87 DPKP, 1844, t. 35, s. 277.

88 APŁ, SPR, Akta tyczące się szkoły elementarnej kolonii Łaznowska Wola w obwodzie rawskim położonej, sygn. 142, APŁ, DGP, Starowa Góra, Powiat Piotrkowski, Szkoła Elementarna Ewangelicka Męska, sygn. 81. 


\section{Podsumowanie}

Rozważania autorów na podstawie dostępnych materiałów źródłowych koncentrowały się na kilku podstawowych zagadnieniach. W pierwszej kolejności badaniom poddano wybrane aspekty funkcjonowania wiejskich szkół ewangelickich w okolicach Łodzi w kontekście ich genezy. W świetle analizy źródeł archiwalnych udało się wychwycić wiele nowych faktów i szereg interesujących prawidłowości. Metryka historyczna obiektów oświatowych była ściśle związana z rozwojem osadnictwa olęderskiego i kolonizacją niemiecką w okresie Prus Południowych. Lokalne wspólnoty miały decydujący wpływ na finansowanie szkół i organizację systemu edukacyjnego. W drugiej części artykułu przeprowadzono analizę przestrzennego oddziaływania szkół, wydzielono podstawowe typy lokalizacyjne i określono współczesny stan zachowania badanych obiektów. Szkoły ewangelickie obejmowały swym zasięgiem zazwyczaj kilka wsi, wystawiano je najczęściej przy zborze ewangelickim, w sąsiedztwie cmentarza lub na skraju zabudowy wsi. Obecnie w krajobrazie wiejskim regionu łódzkiego nie pozostało wiele śladów dawnych szkół o metryce dziewiętnastowiecznej. Przetrwały nielicznie obiekty, które pełnią współcześnie funkcję mieszkaniową albo popadają w ruinę.

\section{Summary}

\section{Evangelical Rural Schools in the Area of Lódź in the $19^{\text {th }}$ Century - Geographical-historical Perspective}

The article includes an attempt to investigate the origins and selected aspects of the activity, location, range of impact and physiognomy of rural evangelical schools, established near Łódź in the $19^{\text {th }}$ century. Geographical and historical analyzes covered the educational facilities founded in the villages associated with the Olęder settlement and German colonization in the period of Southern Prussia. In the first part, the authors examined the issue of the functioning of evangelical schools in the light of archival sources. It made it possible to find many new facts and regularities. In the second part of the article an analysis of the spatial impact of schools was carried out, basic location types were identified and the contemporary state of preservation of the studied objects was determined.

Key words: education, village, historical geography 